\title{
Estimating Ad Valorem Equivalents (AVES) of Non-Tariff Measures: The Case of the Sanitary and Phytosanitary (SPS) and Technical Barrier to Trade (TBT) in Indonesian Bilateral Trade with 20 Main Trade Partners
}

\author{
Tyas Kurniasih*, Maddaremmeng A. Panennungi \\ Economic Planning and Development Policy, Universitas Indonesia, Jakarta, Indonesia \\ "Corresponding author. Email: tyas.kurniasih@gmail.com
}

\begin{abstract}
This study aims to estimate the Ad Valorem Equivalents (AVEs) of the 20 largest trading partner countries of Indonesia as a result of the implementation of the Non-Tariff Measures (NTMs), especially Sanitary Phytosanitary (SPS) and Technical Barrier to Trade (TBT) from 2007 to 2016. AVE can be interpreted as an implicit tax issued by producers in order to meet the SPS and TBT policy requirements. The method used in this research is the quantity impact approach and fixed effect OLS estimator. The result of the SPS and TBT estimation coefficients at the 2-digit Harmonized System (HS) level is transformed into AVE. The result shows that AVEs of SPS and TBT measures for all major trading partners indicate significant differences. That means that the responses of all exporters to Indonesian SPS and TBT measures are varied in terms of sectoral affected and averages. There is also a trend of high GDP per capitacountries havinglow AVEs, while low GDP per capitacountries have high AVEs. NTMs have become protection devices for the government because sectors with low most-favored-nation (MFN) tariffs tend to have high AVEs.
\end{abstract}

Keywords: Valorem Equivalents (AVE), Non-Tariff Measures, Sanitary Phytosanitary (SPS), Technical Barrier to Trade (TBT)

\section{INTRODUCTION}

Regional and multilateral trade cooperation agreements sare aimed to facilitate trade flows and improve the welfare of their members. One of the policy instruments is the reduction of import. For example, there was a significant success in reducing tariffs for non-agricultural products from $6.3 \%$ to $3.8 \%$ in the 1994 Uruguay Round and each member hada commitment to reduce tariffs for each imported product (Schedules of Concession in Goods) (WTO, 2019). However, the decreasing import tariffs was also accompanied by an increasing use of another policy called Non-Tariff Measures (NTMs) (Abbyad and Herman, 2017; Deardorff and Stern, 1997; Li and Beghin, 2014).

Non-Tariff Measures (NTMs) are defined as policies (rather than tariffs) that potentially bring economic effects to international trade, thereby resulting in changes in the quantity of demand, and/or prices of goods(UNCTAD, 2015). NTMs are currently the main problem that has become the topic of discussion in trade negotiations, because NTM effects are expansive, covering many kinds of products, spread over many sectors and cannot easily be quantified. They require certain methods to calculate them and need detailed data on prices and points where NTM mark-up occurs in the supply chain. Contrary to NTM, tariff policy is a relatively transparent policy and is regularly published through certain websites Ferrantino, 2006).

There are two NTM policies commonly used bycountries. They are the Sanitary and Phytosanitary (SPS) policy and Technical Barrier to Trade (TBT) policy. In general, SPS policy aims to protect the health of animals, humans, and plants from the spread of diseases, and contaminants,as well as to ensure the safety of food consumed. TBT contains technical regulations and product standards or requirements 
aimed at protecting human health the environment. To ensure that the SPS and TBT policies do not create trade barriers, the WTO members must fulfill various provisions contained in the TBT and SPS agreements (WTO and UNCTAD, 2012).

Indonesia has been using SPS and TBT measures as technical regulations. On the basis of the Workforce Inventory Tracking System data form, in terms of SPS policy, the plant, leather and food product sector has a coverage ratio and frequency index of more than $75 \%$. However, for the animal sector, the coverage ratio and frequency index have reached $100 \%$, which means that is the sector greatly influenced by the SPS policy applied. From the TBT side, the sectors most significantly affected were animals, fuel, transport, chemicals and footwear, with the coverage ratio reaching $100 \%, 96.64 \%, 81.62 \%, 75.8 \%$ and $68.6 \%$ respectively.

Mandatory implementation of the Indonesian National Standard (SNI) is one example of TBT policies implemented by Indonesia. Until 2018, there were at least 197 SNIs that have been required to be applied by various ministries and institutions that regulate more than 500 products marketed in Indonesia (BSN, 2019). Some examples of products that are required to have SNI are children's toys, baby clothes, steel, fertilizer, technical sulfuric acid, wheat flour, cocoa, rubber hoses, and tires. According to the National Standardization Guideline number 301 of 2007, SNI can be enforced compulsorily if it is related to the interests of national security, safety, public health, or preservation of environmental functions and/or economic considerations. Examples of SPS policies applied by Indonesia are quarantine policies on imported products of fruits, animals, plants, and medicines, maximum limits of microbiological and chemical contamination of processed food products, provisions on the import of animalmeats, offal, and others. The focal point for implementation of the TBT agreement in Indonesia is the National Standardization Agency of Indonesia (BSN) while that of the implementation of SPS agreement is the Agricultural Quarantine Agency, Ministry of Agriculture.

The impact of TBT and SPS policies can be tradeimpeding effects and demand-enhancing effects(Ganslandt and Markusen, 2001). It is called trade-impeding effect because it will increase costs incurred by producers and exporters owing to increased product quality, while the demand-impeding effect is because it can increase product demand as a result of quality assurance and consumer safety. In addition to protecting health, the political and economic motive behind the issuance of NTM policies by a country is to protect the domestic market, also known as protectionism. Protectionism occurs when the policy is deliberately implemented to reduce and inhibit trade with partners, among others by differentiating between foreign and domestic treatment. An example is the application of food product standards that are more stringent than international standards, making it difficult for exporters, especially those from developing countries, especially those in Africa (Herghelegiu, 2018; Kareem, Martínez-Zarzoso and Brümmer, 2018).Recent research has focused on how to quantify the economic effect of NTM into the simple rate or tariff called Ad Valorem Equivalents (AVEs). AVEs can be interpreted as implicit tariffs or implicit rates of protection (Fugazza, 2013). These rates can be compared to import tariffs to show how much the restriction of NTM has affected trade in specific sectors. Since the effect of NTM can be trade-impeding effects or demandenhancing effects, it should be noted that AVEs also produce positive or negative results. AVEs show how much trade costs producers incur so as to meet certain policies to be able to market a product.

Research efforts involving the counting of Indonesia's AVEs generally are cross-country studies (Lee, Nicita and Olarreaga, 2009; Bratt, 2017). Studies related to AVEs, under the Association of Southeast Asian Nations (ASEAN), have been conducted by Cadot et al. (2013) and Ing and Cadot (2017). Studies conducted by Hakim and Panennungi (2018) have calculated the AVE of SPS and TBT policies by Indonesia unilaterally using import data from the rest of the world for the period of 2006-2015 at the product level (6-digit HS), but these studies have not been able to determine the impact of Indonesia SPS and TBT policy to specific trade partners (Hakim and Panennungi, 2018). More than $90 \%$ of total imports to Indonesia come from 20 trade partners (Figure I). The research questions of the present study are (1) How big is the impact of Indonesian SPS and TBT to import from 20 trade partners at the sectoral level calculated as AVEsand (2) Is there any particular pattern between the AVEs of developed exportersand those of developing exporters?.

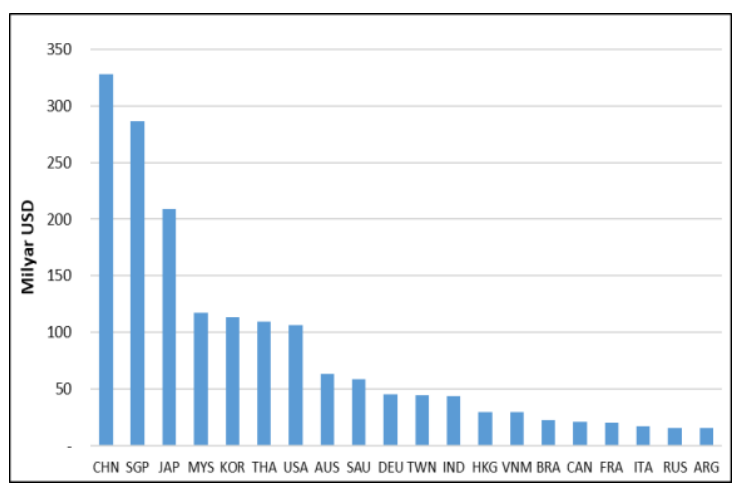

Figure 1. Indonesian Import from Biggest Trade Partners (Bank of Indonesia, 2019).

It is hoped that the contribution of this study will provide empirical evidence of the impact of Indonesian 
SPS and TBT measures on import from 20 specific trade partners calculated as AVEs byusing a quantity-base approach unlike previous research that used a price base approach and import data from the rest of the world.

This study uses import data as HS 2-digit level, from 20 trade partners for the period of 2007- 2016. Estimation of the impact of Indonesian SPS and TBT measures was perform first by the use of a specific model developed by Kee, Nicita and Olarreaga (2009). The estimation was then transformed to AVEs by the use of fixed-effect OLS estimators. The result shows that AVEs for 20 of Indonesia's major trading partners indicated a significant difference, which means that the responses of the 20 exporters related to Indonesian SPS and TBT measures were varied in terms of the affected sector(s) and the average. There is a trend of high GDP per capita countries (developed countries) having low AVEs, because they will be less inhibited to export their product, while developing countries are relatively more inhibited has and have high AVEs. NTMs also have become protection device for the government because sectors with low MFN tariffs tend to have high AVEs.

\section{LITERATURE REVIEW HYPOTHESIS DEVELOPMENT}

AND

\subsection{Non-Tariff Measures}

As mentioned earlier, NTMs are defined as policies (rather than tariffs) that potentially bring economic effects to international trade, thereby resulting in changes in the quantity of demand, prices of goods and or both (UNCTAD, 2015). NTMs can be classified intothree categories, namely: 1) NTMs that apply to imports, with respect to such aspects as quotas, import restrictions, import licensing, custom procedures and administration fees; 2). NTMs that apply to exports, with respect to such aspects as taxes, export subsidies, export quotas, export bans and voluntary export restraints; 3). NTMs that are applied internally in the domestic economy, with respect to rules relating to health, products, labor, environmental standards, internal taxes and subsidies(Staiger, 2012).

The Multi-Agency Support Team (MAST) the Uniter Nations Conference on Trade and Development form an international classification by dividing the types of NTMs into 16 chapters (A to P) and each chapter is divided into several classes according to the type of regulation. NTMs classified to import (A to $\mathrm{O}$ ) and for export measures $(\mathrm{P})$, the import measures are divided up to include the technical measures (A to $\mathrm{C}$ ) and nontechnical measures (D to O). The SPS and TBT measures include the included to technical measures policy (UNCTAD, 2015).

\subsection{Asymmetric Impact of NTM on Exporters}

NTMs implemented by a country can be responded differently by exporting countries, especially NTMs included to technical measure that are identical and implemented by country A but not implemented by country B. Exporting countries will also overcome barriers to NTMs depending on whether the country it also applies the same type of NTM or not in its home country. Some factors that influence this difference are domestic regulation, comparative advantage, the level of welfare of a country, and others. Developed countries can be said to be the most efficient countries that will produce lower cost compliance compared to developing countries (Bratt, 2014; Beghin, Disdier and Stephan, 2013; Marette and Beghin, 2010).

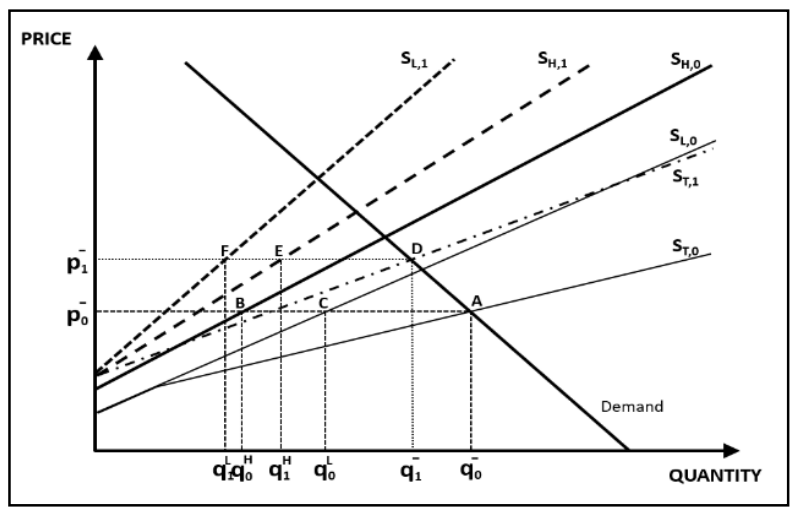

Figure 2 Asymmetrical Impact of the NTM Exporters Face (Bratt, 2014).

\subsection{Impact of NTM on Foreign Producers}

If consumers internalize the possibility of dangerous products that come only from imports, the application of mandatory standards by the government will directly affect imports, especially from foreign producers. This results in a change in supply curves from the supply side of foreign producers only so that the price of the equilibrium product increases (from $\mathrm{pA}^{\prime}$ to $\mathrm{pA}^{\prime}$ ) and reduces imports and domestic consumption (from qA' to qA"). The magnitude of the increase in the price of the new balance will depend on the likely impact on the product, the costs incurred by consumers and the stringency of a standard. 


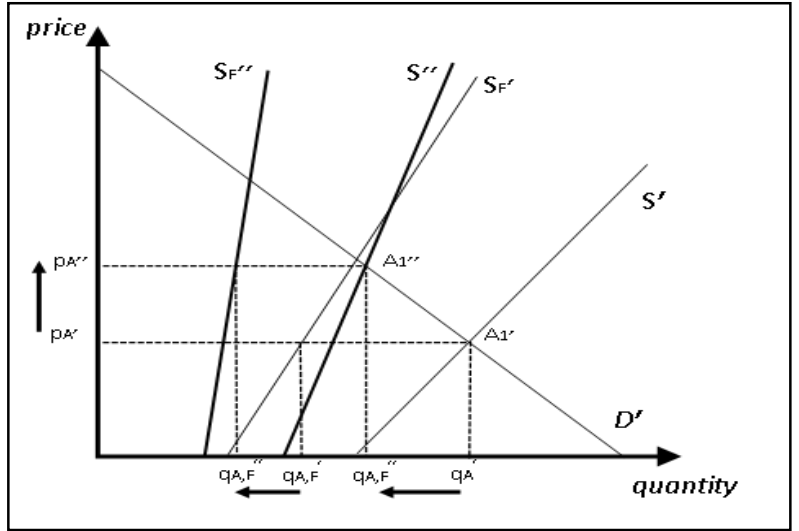

Figure 3 Trade-Impeding Effect of NTM (Disdier and Marrete, 2010).

In addition to internalization, there is also a demandenhancing effect that causes a shift in the demand curve. A standard that is required to provide additional information to consumers and affect consumer behavior. If the policy is informative and signals good quality improvement, it will increase import demand. Consequently, the demand curve will shift to the right, as opposed to the internalization curve of damage by consumers. Implementation of these standards will increase consumer awareness and consequently will increase the incidence of internalization(Fugazza, 2013).

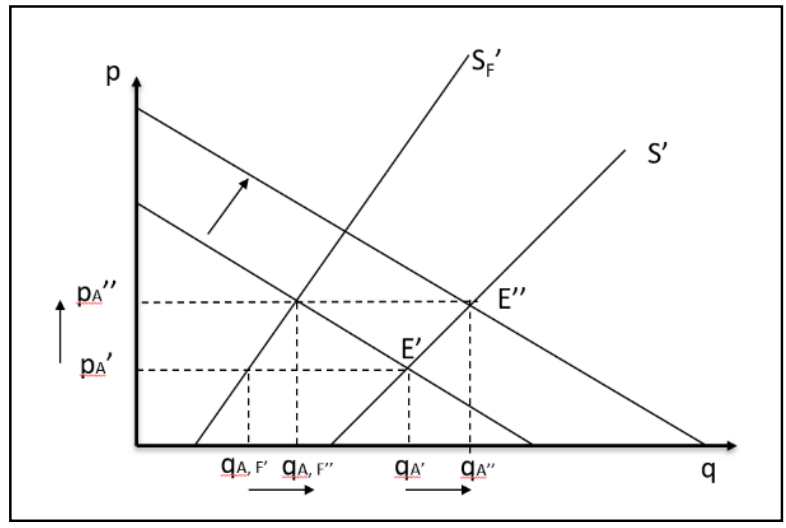

Figure 4 Demand-Enhancing Effect of NTM [22].

\subsection{Quantifying AVEs}

In general, there are two approaches to quantifying NTM, namely the price-based approach and the quantity based approach. Price -gap methods are essentially the assumption that the existence of NTMs will increase the price that consumers must pay. The price difference is checked by comparing the two prices at the two stages of product distribution, namely before and after fulfillment.The NTM uses econometric techniques. The quantity-based approach uses the gravity equation to estimate how much influence NTMs reduce in trading volume, compared to the potential of trade without NTMs (Ferreantino, 2006).
The price-gap method is considered more appropriate than the quantity-gap method, because the former measures the difference between the two observed values, namely the price that is distorted owing to the existence of NTM and undistorted prices (without NTM), whereas the quantity or value gap calculates the difference between the quantity of a product that has been distorted by NTM and the quantity of the product estimated normally (without NTM distortion) which is influenced by the econometric specifications used (Ferrantino, 2006). In contrast, must be noted here that although the price-gap method can be used to estimate the effect of NTM directly, the quantity-based method employs data that are far greater than the price gap, so the results of the analysis have a higher level of confidence Dür, Baccini and Elsig, 2014; Fontagné, Gourdon and Jean, 2013). The quantity-based approach method can be used as the right choice to determine the size of the impact it has on the implementation of an NTM, namely by determining how much a decrease in the quantity of trade caused subsequent to implementing a measure (Jager and Lanjouw, 1977).

Research on how to calculate the impact of NTM implementation has previously been carried out by a number of researchers, including Kee et al. (2009); Dean et al. (2009); Nimenya et al., (2009); Cadot \& Gourdon (2015); Grübler et al., (2016), and Bratt (2017) which are about estimating the cost of fulfilling NTM through AVE.

The foregoing has shown that knowledge and research on AVE in Indonesia is still severely lacking hence the need for this study. Notwithstanding, there is research that has calculated the AVE of SPS and TBT policies by Indonesia unilaterally using import data from rest of the world at the HS level 2002 for the periodof 2006- 2015 at the product level (HS 6 digit). The results of the study state that if technical measures in Indonesia are more of a trade-reducing effect more than the demand-enhancing effect (Hakim and Panennungi, 2018). It is hoped that the contribution of the present study will provide empirical evidence of the impact of Indonesian SPS and TBT measures on import from 20 specific trade partners calculated as AVEs by using a quantity-base approach unlike previous research that used a price-base approach and import data from the rest of the world.

\section{RESEARCH METHOD}

The method used in this study is the measurement of (AVEs) rates on the basis of the quantity impact approach. 


\subsection{Data and Sample}

Observations in this study were carried on Indonesia and 20 main trading partner countries (Table II) at the HS 6 digit level for 10 years, namely 2007-2016. This is due to an increase in the number of TBT and SPS policies following the 2007-2008 global financial crisis as reported by the World Bank and WTO. Import data at the HS 6-digit level were obtained from the WTO and then converted to the Large Trade Price Index from BPS. Data on real GDP with a constant year of 2010 were obtained from the World Bank. Data on TBT and SPS policies applied by Indonesia were obtained from the Trade Analysis and Information System (TRAINS) developed by UNCTAD. NTMs were included in the form of dummy variables in the datasets because TRAINS did not distinguish each NTM on the basis of potential trade barriers and Indonesia can apply more than one NTM on a single line tariff(Bratt, 2017). Data on geographical distance were taken from the Center d'Etudes Prospective et d'Informations Internationales (CEPII), while world oil prices came from the International Energy Agency. Data on endowment were obtained from the World Bank's World Development Indicators and the Penn World Table Version 9.1 (Feenstra, Inklaar and Timmer, 2015). Nominal Exchange Rate data with the base year of 2010 were obtained from the Bank for International Settlements.

\subsection{Research Model}

The model used in this study refers to the research conducted by Kee et al. (2009) and Bratt (2017). The specific model is as follows:

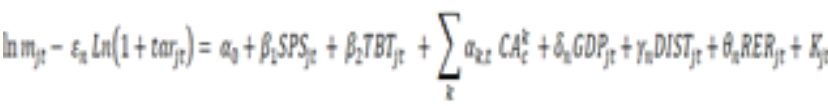

Where

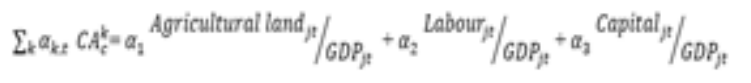

mjt: import value (in $\log$ ) of goods $n$ at 6-digits HS

tarjt: preference tariffs or import duty

$\varepsilon n:$ import demand elasticity

SPSjt \& TBTjt : dummy of SPS \& TBT measures

GDPjt: economic size of country (real)

DISTjt: economic distance

CAck: endowment factor which characterizes country

RERjt: bilateral real exchange rate

$\mu \mathrm{jt}$ : error term

The steps taken to obtain AVEs were as follows:
1. Performing the estimation of equation 3.1 to obtain the variable coefficient $\beta 1$ and $\beta 2$, at the level of HS 2 digits;

2. Transforming the coefficient of the TBT and SPS variables into AVE using equation 3.2 by entering import demand elasticity (Kee, Nicita and Olarreaga, 2009).

The coefficient $\beta 1$ and $\beta 2$ at the HS 2-digit level 2 were then transformed into an AVE with dpricen (domestic price of goods $\mathrm{n}$ ) and squashing factors (Cadot et al., 2013), using the following formula:

$$
\begin{aligned}
& \frac{\delta \ln m_{n}}{\delta T B T_{n}}=\frac{\delta \ln m_{n}}{\delta \ln \text { dprice }_{n}} \frac{\delta \ln \text { dprice }_{n}}{\delta T B T_{n}}=\varepsilon_{n} A V E T B T_{n} \\
& \frac{\delta \ln m_{n}}{\delta S P S_{n}}=\frac{\delta \ln m_{n}}{\delta \ln \text { dprice }_{n}} \frac{\delta \ln \text { dprice }_{n}}{\delta S P S_{n}}=\varepsilon_{n} A V E S P S_{n} \\
& A V E T B T_{n}=\frac{1}{\varepsilon_{n}} \frac{\delta \ln m_{n}}{\delta T B T_{n}}=\frac{e^{\widetilde{\beta 1}}-1}{\varepsilon_{n}} \\
& A V E S P S_{n}=\frac{1}{\varepsilon_{n}} \frac{\delta \ln S P S_{n}}{\delta S P S n}=\frac{e^{\widetilde{\beta 2}}-1}{\varepsilon_{n}}
\end{aligned}
$$

$$
\begin{aligned}
& \widetilde{\beta 1}=1-e^{\beta 1} \\
& \widetilde{\beta 2}=1-e^{\beta 2}
\end{aligned}
$$

Real Effective Rate (RER) is the real exchange rate of the partner country imported to Indonesia. RERnominalratex $\frac{\text { CPI of Partner Country }}{\text { CPI of Indonesia }}$

Economic Distance (DIST) is a variable that represents transportation costs between import countries that are partners to Indonesia multiplied by world oil prices. Thus,

DIST $=$

Geographical distance $\mathrm{I}$ and $\mathrm{j} x \frac{\text { Indonesia's GDP }}{\sum \text { Indonesia }+j \text { GDP }}$

\section{RESULTS}

This analysis focused on the sectors that were affected by specific NTM. SPS was usually imposed on food and agricultural products, while TBT impacted manufactured products of chemical, wood, paper, vehicle, machinery, and so on. 


\subsection{Sanitary and Phytosanitary AVEs}

Table 1. Averages Aves, Sps Measures, by Section and Importer (\%)

\begin{tabular}{|c|c|c|c|c|c|c|c|c|c|c|}
\hline SeCtor & ARG & AUS & BRA & CAN & CHN & DEU & FRA & HKG & IND & ITA \\
\hline$A$ & $\begin{array}{l}- \\
14.76\end{array}$ & 3.52 & $\begin{array}{l}- \\
10.35\end{array}$ & -8.12 & 19.11 & -8.17 & -8.17 & $\begin{array}{l}- \\
10.35\end{array}$ & 16.93 & -6.05 \\
\hline B & 10.82 & 3.64 & -7.69 & 8.23 & 13.49 & 3.64 & 8.23 & 9.41 & 22.04 & 15.75 \\
\hline$C$ & - & - & -9.72 & 10.62 & 10.62 & 10.62 & 10.62 & 9.61 & 10.62 & - \\
\hline$D$ & -9.71 & $\begin{array}{l}- \\
12.10\end{array}$ & $\begin{array}{l}- \\
56.90\end{array}$ & $\begin{array}{l}- \\
28.78\end{array}$ & 6.80 & 1.01 & $\begin{array}{l}- \\
28.97\end{array}$ & -2.00 & - & - \\
\hline $\begin{array}{l}\text { Simple } \\
\text { Average }\end{array}$ & -4.55 & -1.65 & $\begin{array}{l}- \\
21.17\end{array}$ & -4.51 & 12.50 & 1.77 & -4.57 & 1.67 & 16.53 & 4.85 \\
\hline seCtor & JAP & KOR & MYS & RUS & SAU & SGP & THA & TWN & USA & VNM \\
\hline$A$ & 5.07 & -8.13 & 10.20 & -8.17 & -8.15 & 19.29 & -8.17 & -8.18 & -8.20 & 4.80 \\
\hline B & 11.65 & 15.18 & 14.94 & 8.23 & 3.64 & 14.52 & 8.23 & 8.23 & 6.03 & 10.42 \\
\hline$C$ & 10.62 & 10.62 & - & 10.62 & 10.62 & - & 10.62 & 10.62 & 10.62 & - \\
\hline$D$ & -0.13 & -5.86 & $\begin{array}{l}- \\
45.88\end{array}$ & $\begin{array}{l}- \\
28.91\end{array}$ & $\begin{array}{l}- \\
28.94\end{array}$ & 1.38 & $\begin{array}{l}- \\
28.97\end{array}$ & -0.82 & $\begin{array}{l}- \\
17.08\end{array}$ & $\begin{array}{l}- \\
12.10\end{array}$ \\
\hline $\begin{array}{l}\text { Simple } \\
\text { Average }\end{array}$ & 6.80 & 2.95 & -6.91 & -4.56 & -5.71 & 11.73 & -4.57 & 2.46 & -2.16 & 1.04 \\
\hline
\end{tabular}

Note : A: Animal Products (Chapter 01- 05), B: Vegetable Products (Chapter 6-14), C: Animal and Vegetable Fats and Oil (Chapter 15) , D:Food, Beverages and Tobacco (Chapter 16-24). Sign (-): The coefficient obtained is not significant

Table I shows the breakdown of the AVE average for SPS measures by HS sector and 20 trading partners, for agricultural food products (sectors 01-04). Of the 20 countries, 11 countries had an average AVE positive and the rest negative. AVE was highest in India $(16.53 \%)$ and China (12.50\%), namely in animal products (sector 01) and vegetable products (sector 02). India has been recorded as Indonesia's largest meat import partner since 2016, while China has been a partner in imports of vegetable and fruit products. The high costs of compliance incurred by India and China were due to the lack of technical capacity to meet the
SPS regulations required by Indonesia and to monitor their infrastructure. For AVE SPS the highest negative was found in Brazil, namely in food, beverages and tobacco (sector 04). Indonesia imports large quantities of meat and sugar from Brazil, and because of the high level of product quality, the demand for imports from Brazil continues to increase. As the largest supplier of meat and agricultural products, Brazil already has a solid production infrastructure . For this reason, the cost of meeting cost compliance when entering Indonesia is low. 


\subsection{Technical Barrier to Trade AVEs}

Table 2. Averages Aves, TBT Measures, by Section and Importer (\%)

\begin{tabular}{|c|c|c|c|c|c|c|c|c|c|c|}
\hline${ }_{o r}^{S e C t}$ & RG $^{\mathrm{A}}$ & $\mathrm{US}^{\mathbf{A}}$ & $\mathbf{R A}^{\mathbf{B}}$ & $\mathrm{AN}^{\mathrm{C}}$ & ${ }_{\mathrm{HN}}^{\mathrm{C}}$ & $\mathbf{E U}^{\mathbf{D}}$ & $\mathbf{R A}^{\mathbf{F}}$ & $\mathrm{KG}^{\mathbf{H}}$ & $\mathrm{D}^{\mathrm{IN}}$ & $\mathrm{A}^{\text {IT }}$ \\
\hline $\boldsymbol{E}$ & $25^{15 .}$ & $4^{3.1}$ & - & $6^{1.5}$ & $6^{1.5}$ & $6^{1.5}$ & - & - & $04^{16 .}$ & 8 \\
\hline$F$ & 18.49 & $\begin{array}{c}- \\
56.13\end{array}$ & 12.47 & $\begin{array}{ll} & 2.8 \\
5 & \end{array}$ & - & $\begin{array}{c}- \\
33.18\end{array}$ & $27^{17 .}$ & $73^{22 .}$ & 22.11 & $33^{22}$ \\
\hline$G$ & - & - & - & - & - & - & - & 53.43 & - & - \\
\hline $\boldsymbol{H}$ & - & 22.42 & - & - & - & - & - & $96^{16 .}$ & - & 21.36 \\
\hline$I$ & - & $32^{19 .}$ & - & - & $49^{74 .}$ & - & - & - & - & - \\
\hline$J$ & $4^{6.3}$ & $44^{18 .}$ & $33^{11 .}$ & 0.35 & $\begin{array}{c}- \\
20.66\end{array}$ & 54.0 & $35^{10 .}$ & $\begin{array}{c}- \\
10.63\end{array}$ & $4^{7.0}$ & $53^{15}$ \\
\hline $\boldsymbol{K}$ & 26.43 & - & 26.43 & - & 26.33 & - & - & 26.43 & - & - \\
\hline$L$ & - & $43^{19 .}$ & $84^{14 .}$ & - & 32.25 & $43 \quad 19$. & $43^{19 .}$ & $7 \quad 0.4$ & $27{ }^{17 .}$ & $88^{17}$ \\
\hline$M$ & - & - & - & - & - & - & - & - & - & - \\
\hline$N$ & - & 22.82 & 33.86 & - & $\begin{array}{c}- \\
19.83\end{array}$ & - & - & $\begin{array}{c}- \\
18.76\end{array}$ & $\begin{array}{c}- \\
24.39\end{array}$ & $\begin{array}{c}- \\
29.56\end{array}$ \\
\hline$O$ & & $5^{3.8}$ & $\begin{array}{c}- \\
29.72\end{array}$ & 53.8 & 28.95 & 53.8 & $5^{3.8}$ & $58{ }^{18 .}$ & & $65^{15}$ \\
\hline$P$ & - & - & $\begin{array}{c}- \\
29.48\end{array}$ & - & - & $93^{63 .}$ & - & $93^{63 .}$ & & $63^{55}$ \\
\hline$Q$ & - & - & - & - & $72^{18 .}$ & - & - & - & - & - \\
\hline $\boldsymbol{R}$ & - & - & 14.34 & $69^{31 .}$ & - & - & - & $31^{58 .}$ & - & - \\
\hline $\begin{array}{l}\text { Sim } \\
\text { ple } \\
\text { Average }\end{array}$ & 5.83 & 4.65 & $\begin{array}{c}- \\
15.02\end{array}$ & $\begin{array}{ll} & 7.9 \\
2 & \end{array}$ & 4.16 & $\begin{array}{r}9.9 \\
4\end{array}$ & 72 & $\begin{array}{ll} & 7.1 \\
7 & \end{array}$ & $1.23^{-}$ & $6^{9.7}$ \\
\hline${ }_{o r} S e C t$ & $G^{\mathrm{JP}}$ & $\mathrm{OR}^{\mathrm{K}}$ & $\mathbf{Y S}^{\mathbf{M}}$ & $\mathrm{US}^{\mathbf{R}}$ & $\mathbf{U}^{\mathbf{S A}}$ & $G^{S}$ & $\mathrm{HA}^{\mathrm{T}}$ & $\begin{array}{r}\mathbf{T} \\
\mathbf{W N}\end{array}$ & $\mathbf{A}^{\mathrm{US}}$ & $\begin{array}{c}\text { V } \\
\text { NM }\end{array}$ \\
\hline $\boldsymbol{E}$ & $5^{2.3}$ & $94^{28 .}$ & $5^{2.3}$ & $6^{1.5}$ & $6^{1.5}$ & $5^{2.3}$ & & $25^{15 .}$ & $94^{28 .}$ & $27^{15}$ \\
\hline $\boldsymbol{F}$ & $57^{26 .}$ & $90^{47 .}$ & - & 9.56 & $\begin{array}{c}- \\
11.51\end{array}$ & 84.81 & $27^{17 .}$ & $51^{31 .}$ & $8^{4.8}$ & 7.27 \\
\hline$G$ & - & - & $\begin{array}{c}- \\
88.82\end{array}$ & - & 86.37 & 94.82 & - & - & - & - \\
\hline $\boldsymbol{H}$ & - & - & - & - & - & - & - & - & - & - \\
\hline
\end{tabular}




\begin{tabular}{|c|c|c|c|c|c|c|c|c|c|c|c|}
\hline${ }_{o r} \operatorname{SeCt}$ & RG $^{\mathrm{A}}$ & $\mathrm{US}^{\mathrm{A}}$ & $\mathbf{R A}^{\mathbf{B}}$ & ${ }_{A N}^{C}$ & ${ }_{\mathrm{HN}}^{\mathrm{C}}$ & $\mathbf{E U}^{\mathbf{D}}$ & $\mathbf{R A}^{\mathbf{F}}$ & $\mathrm{KG}^{\mathbf{H}}$ & D & IN & $\mathrm{A}^{\mathrm{IT}}$ \\
\hline$I$ & $32 \quad 19$. & - & - & - & 4.00 & 32 & - & - & 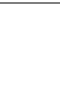 & - & - \\
\hline$J$ & $34 \quad 23$. & 13.65 & $38^{24 .}$ & $7 \quad 0.9$ & 10.96 & $49^{24 .}$ & $35^{10 .}$ & 14.32 & 8 & 3.4 & $4^{2.6}$ \\
\hline$K$ & - & - & 26.27 & 26.43 & 26.43 & - & - & - & & - & 26.38 \\
\hline$L$ & $43^{19 .}$ & $14^{19 .}$ & 43 & - & - & 43 & $43^{19 .}$ & $43^{19 .}$ & 43 & 19. & - \\
\hline$M$ & $\begin{array}{l}9.9 \\
8\end{array}$ & - & - & - & - & - & - & - & & - & - \\
\hline$N$ & 40.25 & 3926. & 21.06 & - & - & 22.45 & - & $64^{37 .}$ & & - & - \\
\hline$O$ & $\begin{array}{ll} & 3.8 \\
5 & \end{array}$ & $\begin{array}{ll} & 3.8 \\
5 & \end{array}$ & $5^{3.8}$ & $\begin{array}{ll} & 3.8 \\
5 & \end{array}$ & $5^{3.8}$ & $5^{3.8}$ & $5^{3.8}$ & $311^{11 .}$ & 5 & 3.8 & \\
\hline$P$ & $\begin{array}{c}- \\
74.47\end{array}$ & - & - & - & - & $\begin{array}{c}- \\
81.68\end{array}$ & - & - & & - & - \\
\hline$Q$ & $722^{18 .}$ & - & $72^{18 .}$ & - & - & $722^{18 .}$ & - & - & & - & - \\
\hline $\boldsymbol{R}$ & - & - & $\begin{array}{c}- \\
18.77\end{array}$ & - & - & - & - & - & & - & - \\
\hline $\begin{array}{l}\text { Sim } \\
\text { ple } \\
\text { Average }\end{array}$ & 80.8 & $76^{18 .}$ & 9.58 & 5.92 & 19.12 & 19.56 & 72 & $80^{16 .}$ & 12 & 12. & 3.93 \\
\hline
\end{tabular}

Note :E: Minerals (Chapter 25-27), F: Chemincals (Chapter 28- 38), G: Plastic (Chapter 39- 40), H: Leather (Chapter 41- 43), I:Wood Materials (Chapter 44- 49), J: Textile (Chapter 50- 63), K: Footwear (Chapter 64- 67), L : Stone and glass (Chapter 68- 70),M : Pearls (Chapter 70), N: Metals (Chapter 72- 83), O: Machinery (Chapter 84- 86), P: Vehicles (Chapter 87- 89), Q: Optical and medical instruments (Chapter 90- 92), $R$ : Miscellaneous (Chapter 94- 96). Sign (-): The coefficient obtained is not significant

Table II shows the breakdown of the AVE average for TBT measures, by sector and the 20 trading partners, and also for minerals, industry and manufacturing (sectors 05-20). Of the 20 countries, 11 countries had a positive AVE and the rest were negative. The highest AVE TBT was found in South Korea (18.76\%) and the lowest in Singapore 19.12\%). From 2013 to 2016, Korea declared an increase in trade barriers, not only from ASEAN but from several of its major trading partners (KH디지털2, 2016). On the basis of BPS data, South Korea's main imports to Indonesia were minerals, chemicals and plastic and rubber and chemicals were the sectors with the highest number of TBT regulations, which were 21 regulations resulting in high cost compliance confronted by South Korea. At the time of this study, Singapore was a member of a group of high-income countries that from the manufacturing and service sectors had the largest contribution to economic growth.Owing to the presence of good industrial infrastructure, the country has not experienced export barriers to
Indonesia. This also explains that Singapore had the lowest AVE for the plastic sector.

The sector that had the highest AVE TBT was the wood material sector from China. Although Indonesia and China were among the largest exporters of wood products in the world, Indonesia still imported wood for raw materials from China. The existence of strict regulations regarding timber imports since Indonesia imposed the Timber Legality Verification System policy in 2014 has been estimated to be a reason for delays in timber imports from China. Timber imports were tightened by making rules on the Timber Legality Certificate for importers. Obligations to make TLVs and the process of making these import recommendations could be a major obstacle. 


\subsection{AVES VS GDP Percapita}

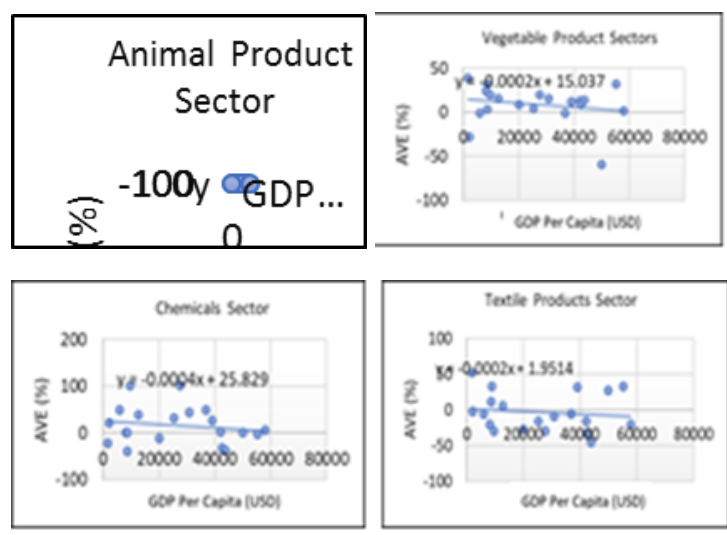

Figure 5 Trend of AVEs (SPS and TBT) VS GDP Per Capita at Certain Sectors.

\subsection{AVEs vs MFN Tariffs}

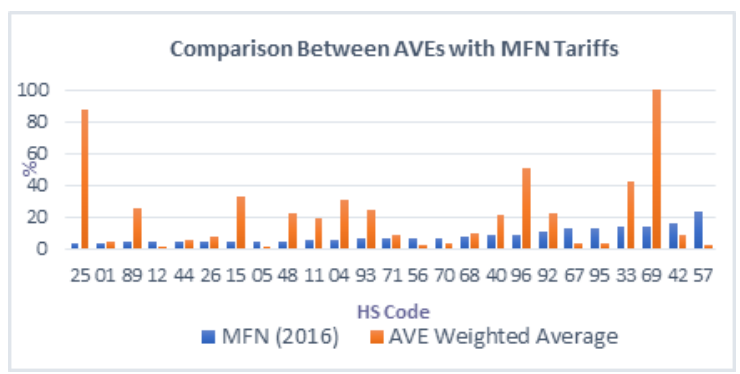

Figure 6 Comparison between AVEs (SPS and TBT) VS MFN Tariffs.

NTMs, especially SPS and TBT, are technical regulations that are officially designed to achieve certain public policy objectives, and are generally imposed on many sectors so that they can be used as political economic reasons, i.e. unnecessary barriers to trade (WTO, 2019). The protectionism motive can be characterized by high AVE in sectors that have high import competition, which is characterized by the large number of workers needed, but in those sectors subject to high NTM (Herghelegiu, 2018).

It can be observed that there was a significant difference between the total AVE SPS and TBT against MFN rates. The milk-based product sector (HS 04), milling industry products (HS 11), animal fats and oil (HS 15), salt (HS 25), cosmetics (HS 33), rubber (HS 40), paper (HS 48), ceramics (HS 69), ships (HS 89), and other production products (HS 96) had AVEs that were higher than the MFN tariff. This shows that the Government of Indonesia had a tendency to be protectionist in regulating SPS and TBT regulations in the sector.

\section{CONCLUSION AND IMPLICATIONS}

This study shows that AVEs for 20 of Indonesia's major trading partners there was a significant difference, in that, the responses of the 20 exporters related to Indonesian SPS and TBT measures were varied in terms of the sector affected and its average. The study also reveals a trend in which high GDP per capita countries (develop countries) have low AVEs, while those for developing countries are high. NTMs also have become protection devices for the government because sectors with low MFN tariffs tended to have high AVEs.

In addition, in conducting trade negotiations, the government could in the future carry out an assessment of AVE NTMs imposed by a country. This could be done as a preliminary study to ensure the level of restriction of the country's policy toward Indonesia and vice versa so that it could become a consideration and input for decision makers.

\section{RESEARCH LIMITATION}

This research is limited to AVE analysis based on bilateral import data from trade partner countries to Indonesia. For this reason, further research needs to be done by using more country samples and bilateral export trade data in a two-way effect to be able to calculate relevant bilateral AVE.

\section{REFERENCES}

[1] Abbyad, N. and Herman, P. 'How Much Do Non-Tariff Measures Cost?: A Survey of Quantification Methods', Economics Working Paper Series, 2017.

[2] Beghin, J., Disdier, A. and Stephan, S. 'Trade Restrictiveness Indices in Presence of Externalities: An Application to Non-Tariff Measures', Working Paper No. 12023, no. July 2013, p. 36.

[3] Bratt, M. 'Estimating the Bilateral Impact of Nontariff Measures on Trade', Review of International Economics, 25(5), 2017, pp. 11051129.

[4] Bratt, M. 'Estimating the Bilateral Impact of Non-Tariff Measures (NTMs), no. 14011, Institut d'Economie et Econométrie, Université de Genève, 2014.

[5] BSN, 'Daftar Produk yang Wajib Memenuhi SNI', 2019.

[6] Cadot, O. and Gourdon, J. 'NTMs, Preferential Trade Agreements and Prices: New Evidence', [Online], Available 
https://pdfs.semanticscholar.org/61de/76dc522f 17d14502c659af23bf81dcf6d32d.pdf?_ga=2.42 459619.71041976.1571544206734747605.1571544206, 2015, pp.1-26.

[7] Cadot, O., Munadi, E. and Ing, L. 'Streamlining NTMs in ASEAN : The Way Forward', ERIA Discuss. Pap. Ser., no. ERIA-DP-2013-24, 2013.

[8] Dean, J., Signoret, J., Feinberg, R., Ludema, R. and Ferrantino, M. 'Estimating the Price Effects of Non-Tariff Barriers,' B.E. Journal of Economic Analysis \& Policy, 9(1), 2009.

[9] Deardorff, A. V., and Stern, R.M. 'Measurement of Non-Tariff Barriers,' Vol. 179, University of Michigan Press, 1997.

[10] Disdier, A and Marette, S. 'The Combination of Gravity and Welfare Approaches for Evaluating Nontariff Measures,' American Journal of Agricultural Economics, 92(3), 2010, pp. 713726.

[11] Dür, A., Baccini, L. and Elsig, M. 'The Design of International Trade Agreements: Introducing a New Dataset,' Review of International Organisations, 9(3), 2014, pp. 353-375.

[12] Feenstra, R., Inklaar, R. and Timmer, M. 'The Next Generation of the Penn World Table PWT 8.0,' The American Economic Review, 105(10), 2015, pp. 3150-3182.

[13] Ferrantino, M. 'Quantifying the Trade and Economic Effects of Non-Tariff Measures,' OECD Trade Policy Pap., 28(28), 2006, p. 70.

[14] Fontagné, L., Gourdon, J. and Jean, S. 'Translantic Trade: Whither Partnership, Which Economic Consequences?,' Policy Br. CEPII, no. 1, 2013, pp. 1-12.

[15] Fugazza, M. 'The Economics Behind NonTariff Measures: Theoretical Insights and Empirical Evidence,' Policy Issues Int. Trade Commod. Study Ser., no. 57, 2013.

[16] Ganslandt, M. and Markusen, J. Standards and Related Regulations in International Trade: A Modeling Approach, (no. w8346), National Bureau of Economic Research, 2001.

[17] Grübler, J., Ghodsi, M. and Stehrer, R. 'Assessing the Impact of Non-Tariff Measures on Imports,' The Vienna Institute for International Economic Studies, 2016.

[18] Hakim, I. and Panennungi, M. 'No Title,' in The Impact of Indonesian Non-Tariff Measures on Import : The Case of Sanitary and Phytosanitary
(SPS) and Technical Barriers to Trade (TBT), 2018.

[19] Herghelegiu, C. 'The Political Economy of Non-Tariff Measures,' World Economy, 41(1), 2018, pp. 262-286.

[20] Indonesia, B. 'Statistik Ekonomi dan Keuangan, Indonesia,. [Online]. Available at: https://www.bi.go.id/id/statistik/seki/terkini/mo neter/Contents/Default.aspx. Accessed 5 April, 2019.

[21] Ing, L. and Cadot, O. 'Ad valorem equivalents of non-tariff measures in ASEAN'.ERIA Discussion Paper Series, ERIA-DP-2017-09, 2017.

[22] Jager, H. and Lanjouw, G. 'An Alternative Method for Quantifying International Trade Barriers,' Review of World Economics, 4(1977), 1977, pp. 719-740.

[23] Kareem, F., Martínez-Zarzoso, I. and Brümmer, B., 'Protecting Health or Protecting Imports? Evidence from EU Non-Tariff Measures,' International Review of Economics \& Finance, 53(August 2017), 2018, pp. 185-202.

[24] Kee, H., Nicita, A. and Olarreaga, M. 'Estimating Trade Restrictiveness Indices,' The Economic Journal, 119(534), 2009, pp. 172199.

[25] Kee, H., Nicita, A. and Olarreaga, M. 'Import Demand Elasticities and Trade Distortions', The Review of Economics and Statistics, 90(4), 2005, pp. 666-682.

[26] KH디지털2, 'Korea Faces Increased Non-Tariff Barriers,' The Korea Herald, 2016.

[27] Li, Y. and Beghin, J. 'Protectionism indices for non-tariff measures: An application to maximum residue levels,' Food Policy, vol. 45, 2014, pp. 57-68.

[28] M. Ferrantino, 'Quantifying the Trade and Economic Effects of Non-Tariff Measures,' OECD Trade Policy Papers, 28(28), 2006, p. 70.

[29] Marette, S. and Beghin, J. 'Are Standards Always Protectionist?,' Rev. Int. Econ., 18(1), 2010, pp. 179-192.

[30] Nimenya, N., De Frahan, B. and Ndimira, P. 'A Tariff Equivalent of Non-Tariff Measures : The Case of European Horticultural and Fish Imports from African Countries, Agricultural Economics (43), 2013, pp. 635-653. 
[31] Staiger, R. 'Non-tariff Measures and the WTO Non-Tariff Measures and the WTO', Economic Research and Statistics Division Working Paper, no. 2012-01, 2012.

[32] UNCTAD, 'International Classification of NonTariff Measures'. Geneva: United Nations Conference on Trade and Development, 2015.
[33] WTO and UNCTAD, 'Analyzing bilateral trade using the gravity equation,' A Practical Guide to Trade Policy Analysis, 2012, pp. 101-136,

[34] WTO, 'Non-Agriculture Market Access Negotiations.,'. [Online]. Available at: https://www.wto.org/english/tratop_e/markacc e/markacc negoti, 2019. 